\title{
MANAGEMENT OF ALLIANCE PORTFOLIOS AND THE ROLE OF THE BOARD OF DIRECTORS
}

\author{
Ignacio CASTRO ${ }^{1}$, José L. GALÁN ${ }^{2}$, Cristóbal CASANUEVA ${ }^{3}$ \\ Department of Business Administration and Marketing, \\ Universidad de Sevilla, Av. Ramón y Cajal, $n^{\circ} 1.41018$ Seville, Spain

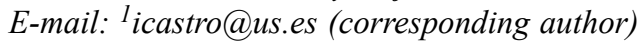

Received 31 January 2014; accepted 21 August 2014

\begin{abstract}
The objective of the present work consists in testing whether the strategic involvement of boards of directors has a positive influence on the development of alliance portfolio management capability and on the value that the alliance portfolio generates. A variance-based structural equation modelling (Partial Least Squares) has been applied to a sample constituted by 139 top Spanish companies. Our analysis shows that the strategic involvement of the board of directors has a positive and influence on the management of alliance portfolios, thereby influencing the value of that portfolio in an indirect way. Unlike previous literature, this study links the functions of the board of directors to organizational capabilities, connecting the literature on corporate governance and on management of alliance portfolios.
\end{abstract}

Keywords: alliance portfolio management capability, alliance portfolio value, board composition, corporate governance, multiple mediating model, partial least squares, strategic implications of boards of directors.

JEL Classification: M1.

\section{Introduction}

Strategic alliances have become a valuable strategic tool for firm competitiveness (Schilke, Goerzen 2010), because they constitute an appropriate mechanism to redress certain shortages of resources (Hoffmann 2005) in increasingly competitive business environments that fluctuate sharply. These alliances have generally been studied in the literature from an atomistic perspective (dyadic ties) (Granovetter 1992; Schreiner et al. 2009). In practice, nevertheless, firms involve themselves in simultaneous strategic alliances with multiple partners establishing important interorganizational networks. It has been pointed out, over recent years, that firms should be capable of strategic management of all these network resources, stimulating their mobilization and enabling access to them, thereby applying a holistic approach to the management of their alliance portfolios (Wassmer, Dussauge 2012).

Alliance portfolio management requires the development of a specific organizational capability. So, alliance portfolio management capability may be defined as the capabil- 
ity of a firm to develop alliance portfolio strategies, to establish a management system and to coordinate and to control the portfolio as a whole, facilitating the combination and the transfer of resources between actors (Hoffmann 2005).

There is little or no literature on the possible factors and variables that could influence the development and the execution of this capability to manage alliance portfolios. As this is a strategic capability, Hoffmann (2005) pointed out that the board of directors needs to involve itself in central alliance portfolio management and should assume a particular role and position. In a broader sense along these same lines, some researchers propose that there is a need to analyse alliance portfolios from the perspective of corporate governance (Reuer, Ragozzino 2006; Wassmer 2010). Thus, numerous examples of alliance portfolios constitute a mixture of strategic alliances with little coordination and conflicting demands. Corporate governance might perhaps be able to provide explanations for these disparities in the results.

In short, some authors (McNulty, Pettigrew 1999) have identified a gap in the literature, as on the one hand, it is recommended that boards of directors should involve themselves more in strategy, although, on the other hand, there are few empirical studies that analyse this role, and none that relate to strategic management of their alliance portfolios. Therefore, it is our intention to explore the following central question: Will the strategic involvement of a board of directors influence alliance portfolio value through the dimensions of its alliance portfolio management capability? In order to achieve this objective, our investigation analyses the influence of the board of directors on alliance portfolio management, conducting an in-depth study of this capability that has only recently been construed, either as a set of independent dimensions (Sarkar et al. 2009; Schreiner et al. 2009), or as a single construct (Schilke, Goerzen 2010). With this aim in mind, this paper proposes a multiple mediation model (Hayes et al. 2011), in order to investigate the mediating role of the dimensions of alliance portfolio management capability on the relationship between the strategic implication of boards of directors and alliance portfolio value.

In conclusion, this work makes a theoretical and a practical contribution. The main theoretical contribution of this investigative study is to analyse the role that the boards of directors might have, centring on the management of alliance portfolios. At an empirical level, the study shows that the strategic involvement of the board of directors has a positive and significative influence on the different organizational processes linked to the management of alliance portfolios, thereby influencing the value of that portfolio in an indirect way.

\section{Theoretical background}

\subsection{Alliance portfolio management capability and alliance portfolio value}

Alliance portfolio management capability may be defined as an adeptness at identifying partners, the initiation of strategic alliances, the participation of the firm in continuous management, and the possible restructuring and even completion of such alliances (Khanna et al. 1998). Accordingly, this capability requires a series of organizational 
processes or dimensions. Sarkar et al. (2009) identifies three dimensions. Firstly, a proactive dimension that aims to span the organizational routines that are followed to constitute the alliance portfolio (partnering proactiveness) (Tang 2011). Secondly, a relational dimension that gathers together the focal actor's skills to develop cooperative models that are characterized by mutual trust and the minimization of opportunistic behaviours (relational governance) (Sepulveda, Gabrielsson 2013). The third and final process is an integration dimension, which aims to cover knowledge transfer processes and other types of resources through the different channels that form the focal actor's portfolio (portfolio coordination) (Lahiri, Narayanan 2013).

An important question resides in how to evaluate and to determine the value of an alliance portfolio, as that value is more than the simple sum of the individual alliances and the value that each one generates. Optimum management, therefore, of a portfolio should generate synergies, economies of scale and scope, and positive spillovers for the focal actor (Sarkar et al. 2009). In this sense, Hoffmann (2005) pointed to a need for two types of factors in any assessment of an alliance portfolio. The output factors refer to financial performance factors (profit, cashflow), as well as to the achievement of strategic aims (market share) (Sarkar et al. 2009; Schilke, Goerzen 2010). The input factors are centred on the quantity and quality of the resources supplied by the partners in the portfolio. This also covers such questions as the quality of their relationships (Hoffmann 2005). On this point, Sarkar et al. (2009) developed the concept of alliance portfolio capital as a critical source of competitive advantage, consisting of an aggregate of interorganizational resources that are linked to a focal actor through its participation in a set of alliances.

\subsection{Boards of directors and alliance portfolios}

The literature on corporate governance has fundamentally centred on the control function based on agency theory. In this area, researchers have studied the way in which strategic decisions taken in the context of fusions, take-overs and corporate diversification are affected by agency problems. Some authors consider that this whole current of research should be applied analogously to alliance portfolio management (Reuer, Ragozzino 2006; Wassmer 2010).

The literature points to another important responsibility of the board of directors, which is the service/collaboration function (He et al. 2010). Stewardship theory challenges the logic that is upheld by agency theory, arguing that the interests of managers and board members do not necessarily collide (Muth, Donaldson 1998). From this perspective, the role of the board is to assess and to participate in the strategic decisions of the firm. Accordingly, Huse and Zattoni (2008) proposed that a continuum may be observed which would reveal the varying degrees of commitment and task involvement of the board of directors. At one end of the spectrum, the passive board of directors would be found, which gathers no information from the firm and simply rubber stamps all executive decisions; and, at the other end, is the board of directors, which actively participates and is involved in the decisions of the firm. In this work, understanding that control and service functions are closely related and should be developed and analysed at the 
same time (Roberts et al. 2005), we are going to study how the involvement strategy of these boards of directors in their management of the alliance portfolio impacts on the value of the alliance portfolio through the dimensions that constitute the alliance portfolio management capability.

\section{Hypotheses}

\subsection{The relationship between the strategic involvement of boards of directors and the alliance portfolio value}

Various studies have described the relation between corporate governance and organizational performance in the literature (Heracleous 2001). So, Zahra and Pearce II (1989) point out that the impact of the boards of directors on the performance of the firm can occur, on the one hand, through the attributes of the board and, on the other hand, through the functions that it performs. In relation to the roles or functions performed by the board of directors, some researchers have pointed out that the active participation of directors in the strategic decisions will impact directly on any improvement in firm performance (Ruigrok et al. 2006). This would imply, in our work, that the mere participation of the directors in the strategic discussions of the firm will increase its alliance portfolio value. In accordance with these ideas:

H1: The strategic involvement of the board of directors is positively related to the value of the alliance portfolio.

\subsection{The mediating role of the partnering proactiveness}

The partnering proactiveness dimension was defined by Sarkar et al. (2009) as the capability of the firm to discover to new alliance opportunities ahead of its competitors and to respond to them. These strategic decisions entail agency hazards such as the selection of an alter and the establishment of an alliance could be motivated by an opportunity for the managers, in terms of increased status or prestige that could turn into external employment opportunities (Reuer, Ragozzino 2006), rather than by a real opportunity to increase the value of the firm and, therefore, to favour the interests of firm owners. Accordingly, the active involvement of the boardroom directors in the strategic decisions of their firms forces the managers to analyse the proposals in greater depth, before making their decisions, which could optimize the choice of an alter (Ruigrok et al. 2006). In addition, the knowledge, the capabilities and the relations of the boards of directors could facilitate the identification of new openings for alliances (Wincent et al. 2010). In this sense, directors with a high number of valuable external relations may facilitate the identification of and the response to alliance opportunities (Kor, Sundaramurthy 2009). For these reasons, it is proposed that the involvement of the boards of directors in strategic decision will impact on partnering proactiveness.

Likewise, Sarkar et al. (2009) established that the partnering proactiveness dimension would positively influence the value of the focal actor's alliance portfolio; an advantage of the benefits of first-movers as much as the optimum selection of partners and the development of relational patterns that benefit the focal actor (Oerlemans et al. 2013). In accordance with these ideas: 
H2: The relationship between the strategic involvement of the board of directors and alliance portfolio value is positively mediated by partnering proactiveness.

\subsection{The mediating role of relational governance}

The role of relational governance in the portfolio refers to the capability of the focal actor to develop informal self-enforcing safeguards in the relationships that constitute the portfolio in which the partners' opportunistic behaviour is minimized. In this way, the directors could be more concerned about portfolio growth and the expansion of the interorganizational network with a view to signalling their own capabilities, rather than strengthening existing ties (Reuer, Ragozzino 2006). So, the strategic involvement of the board of directors in relational governance of the alliance portfolio, through the contribution of knowledge, capabilities and relations (interlocking directorates), could strengthen the ties that constitute the alliance portfolio, minimizing the opportunistic behaviour of the alters, as well as complementing governance mechanisms of a formal nature with other more informal ones based on trust (Kor, Sundaramurthy 2009; Ruigrok et al. 2006; Simoni, Caiazza 2012).

Likewise, Sarkar et al. (2009) noted that the relational governance dimension is associated with alliance portfolio value. Accordingly, these researchers established that the better the relational quality of the focal actor with strategic partners which make up the portfolio, the greater the value of the alliance portfolio. We therefore hypothesize as follows:

H3: The relationship between the strategic involvement of the board of directors and alliance portfolio value is positively mediated by relational governance.

\subsection{The mediating role of the portfolio coordination}

The main objective of the dimension portfolio coordination is to manage the multiple relationships and their interdependences, with the objective of transforming the focal actor's portfolio into a coherent set of interorganizational strategic resources (Sarkar et al. 2009). Reuer and Ragozzino (2006) proposed that managers might feel a greater incentivize to signal their own capabilities as directors to a particular partner, looking for individual employment opportunities rather than seeking advantages for the aforementioned portfolio. In addition, the overall view of the firm held by the board of directors, and the debates that these directors will have in the adoption of strategic decisions, will allow the identification of opportunities in terms of coordination and mobilization of the resources of the alters (Ruigrok et al. 2006). The strategic involvement of the board of directors in the coordination of the portfolio could guarantee more effective and efficient holistic management of portfolio flows in such a way as to achieve collaborative synergies, economies of scale and scope, positive spillovers and, to avoid negative conflicts.

Likewise, some authors pointed out that the portfolio coordination dimension is related with alliance portfolio value (Sarkar et al. 2009; Schilke, Goerzen 2010). Accordingly, it would be logical to imagine that the coordination and mobilization of valuable network resources (Casanueva et al. 2014; Sluyts et al. 2011) will raise the likelihood of 
an increase in alliance portfolio value. Based on this logic and on previous research, we hypothesize as follows:

H4: The relationship between the strategic involvement of the board of directors and alliance portfolio value is positively mediated by portfolio coordination.

\section{Research methodology}

\subsection{Sample}

The primary data required to test our hypothesis was gathered from guided or supervised questionnaires administered by interviewers. We created a list of 500 firms among the top Spanish companies listed on the INFORMA D\&B and SABI databases. Initial contact with the firms on the list was by telephone. A total of 199 expressed a willingness to collaborate and an appointment was arranged to work through the guided questionnaire, which was administered by a team of surveyors. Of the almost 200 firms, 61 were removed when incompliance with the established requirements was noted. Our final sample was therefore 139 large Spanish firms, which presented the following average data for 2011: turnover of $€ 214,077,501$, a workforce of 427 employees and an average age of 27.27 .

These firms were requested to have, on the one hand, a director respond to the questions relating to the characteristics and operation of the board of directors and, on the other hand, that a manager attached to the alliance function respond to the questions on alliance portfolio management. In relation to this latter part, with the objective of maximizing data accuracy and reliability, given that the information was obtained from a single informant, we analysed halo effects following the procedure described by Liang et al. (2007). So, a new factor called "method" was introduced in the research model. This method factor included all the principal indicators of the construct. In this way, the variance of each indicator was explained for both the principal construct and the factor method. Our results show an average substantively explained variance of the indicators of .684 and an average method-based variance of .010. The ratio of substantive variance to method variance is about $68.4: 1$. In addition, none of the method factor loadings are significant. Therefore, the common method bias is unlikely to cause serious concern in this study.

\subsection{Measures}

Table 1 shows individual items and their loadings on relevant constructs, so as to understand the measurements of the dependent, the independent and the control variables more clearly. All measurements items, except certain variables (company size, board size, board composition, board rotation and CEO duality), were assessed on a 7-point Likert Scale ranging from strongly disagree (1) to strongly agree (7).

\subsubsection{Dependent variable: the alliance portfolio value}

Hoffman (2005) showed that two types of factors can be used to calculate the value of an alliance portfolio: output and input. Along these lines, output factors aim to gather the portfolio's performance. To achieve this objective some authors (Schilke, Goerzen 
2010) consider that this approach is appropriate, if the respondents represent top-level management and express their satisfaction with the performance of the portfolio. Therefore, the alliance portfolio was measured in terms of performance satisfaction. We used a four-item scale that was developed based on Schilke and Goerzen (2010). The four indicators loaded onto one factor. We used the factor scores as a composite measure for the alliance portfolio performance (Managers assess performance in terms of their overall satisfaction with the alliance, or in terms of the extent to which an alliance has met its stated objectives). Managerial assessments of alliance performance received some initial criticism for reasons of bias and inaccuracy. This was especially true until research by Geringer and Hebert (1991) demonstrated the existence of a high correlation between subjective assessments of performance with more objective measures, based on accounting data. Thus, there is an emerging consensus among scholars that, if properly done, managerial assessments are a reasonable way to assess alliance performance (Das, Teng 2000). On the other hand, input factors reflect the quantity and quality of the resources which the partners that make up the portfolio supply. The alliance portfolio capital was measured with a three-item scale that was developed based on Sarkar et al. (2009). With these three indicators we did a principal components factor analysis with varimax rotation to develop a composite measure. The three indicators were loaded onto one factor and we then used the factor scores as a composite measure for alliance portfolio capital. Finally, we used the factor scores as a composite measure for Alliance portfolio value (APV).

\subsubsection{Independent variables: the strategic involvement of the boards of directors and the dimensions of alliance portfolio management capability}

The data on the board's involvement in strategic decision-making were extracted from our sample. The Strategic involvement of the board of directors (SIBD) variable was modelled according to a composite latent construct model. Measurement of this construct involved five reflective indicators. So, the directors were asked to rate board involvement on a seven-point Likert scale for each of the five features of the strategic decision-making process (Ruigrok et al. 2006).

The dimensions of alliance portfolio management capability (Partnering proactiveness (P_PRO), Relational governance (R_GOV) and Portfolio coordination ( $\mathrm{P}$ _COOR)) were measured with a five-item Likert scale which was adapted from the literature (Sarkar et al. 2009; Schilke, Goerzen 2010).

\subsubsection{Control variable: the size of the firm, alliance experience and alliance function}

We controlled for company size as the logarithm of the number of employees and for alliance experience and alliance function which was measured on a seven-point Likert scale (Sarkar et al. 2009). Accordingly, large firms with extensive experience in alliances and with a dedicated alliance function may have greater capabilities to assign resources and to exploit knowledge for the development of alliance portfolio management routines (Ruigrok et al. 2006; Vandaie, Zaheer 2014). 


\subsubsection{Explicative variables (antecedents) of strategic involvement: board size, board composition, board directors rotation and CEO duality}

Our analysis includes a series of antecedent variables of the strategic involvement of the board of directors that have been described in the literature (Pearce II, Zahra 1992). Board size was operationalized as the total number of directors on the board. Board composition was operationalized as the proportion of outsider directors to total board size. Besides, Ruigrok et al. (2006) highlighted CEO Duality as an important antecedent variable of the strategic involvement of the board (1 if the CEO and was the same person as the director of the board and 0 if otherwise). Finally, rotation was used as a proxy of board expertise (Zahra, Pearce II 1990) which was measured as a dichotomous variable ( 1 if changes had occurred over the last three years in the council and 0 if otherwise).

\subsection{Data analysis and results}

\subsubsection{Data analysis}

Tests on the research model, with the assistance of Smart PLS 2.0. M3 software (Ringle et al. 2005) were applied Partial Least Squares (PLS), a variance-based structural equation modelling technique (Henseler et al. 2009).

PLS is primarily intended for causal-predictive analysis, in which the problems explored are complex and prior theoretical knowledge is scarce. Consequently, PLS is an appropriate technique to use in a theory-development situation that is the case of this study. PLS has also been chosen because this contribution focuses on the prediction of dependent variables. The use of PLS with regard to covariance-based structural equation modelling (maximum-likelihood) is also recommended due the sample size $(\mathrm{n}=139)$ (Castro, Roldán 2013).

\subsubsection{Measurement model}

The evaluation of the reflective measurement models examines its reliability and validity (Henseler et al. 2009). First, all standardized loadings $(\lambda)$ exceeded the 0.707 level (Table 1), except for one item from the relational governance dimension, but as this construct complied with the two conditions that are analysed further on, we decided to maintain it. Therefore, individual item reliability was acceptable. Second, the five latent variables met the requirement of construct reliability, as their composite reliabilities $\left(\rho_{c}\right)$ were greater than 0.7 (Table 1). Such constructs achieve convergent validity, because their average variance extracted (AVE) measures exceed the level of 0.5 (Table 1). Finally, all latent variables achieved discriminant validity. This is calculated by a comparison of the square root of the AVE with the correlations between the constructs (Table 2).

\subsubsection{Structural model}

As Henseler et al. (2009) note, the use of bootstrapping (5000 resamples) generates standard errors and t-statistics to evaluate the statistical significance of the path coefficients. Simultaneously, calculation of the bootstrapping confidence intervals of standardized regression coefficients forms part of the analysis. As shown in Figure 1B, six 
of seven direct effects are significant. This outcome is also achieved observing the percentile bootstrap 95\% confidence interval. From the analysis of these results, we can conclude that $\mathrm{H} 1$ is not supported. The direct effect of the strategic implication of the boards of directors on the alliance portfolio value (c') is not significant and its confidence interval includes zero. The results summarized in Table 3 confirm that the predictive relevance of the structural model is satisfactory for alliance portfolio value $\left(Q^{2}=0.420\right)$.

In order to test the mediation hypotheses (H2-H4), we have applied the analytical approach described by Hayes et al. (2011). Figure 1A describes the total effects of the strategic implication of the boards of directors (c) on the alliance portfolio value. Figure $1 \mathrm{~B}$ expresses the total effect of the strategic implication of the boards of directors on the alliance portfolio value as the sum of the direct (c') and indirect effect (a1b1 + a2b2 + $\mathrm{a} 3 \mathrm{~b} 3)$. Thus, $\mathrm{c}=\mathrm{c}^{\prime}+\mathrm{a} 1 \mathrm{~b} 1+\mathrm{a} 2 \mathrm{~b} 2+\mathrm{a} 3 \mathrm{~b} 3$, where $\mathrm{c}^{\prime}$ is the direct effect of the strategic implication of the boards of directors on the alliance portfolio value $(\mathrm{H} 1)$, controlling for three mediators (partnering proactiveness, relational governance and portfolio coordination). This method has the advantage of being able to isolate the indirect effect of mediating variables, that is, the partnering proactiveness $(\mathrm{H} 1$ : alb1), relational governance (H2: a2b2) and the portfolio coordination (H3: a3b3).

The application of bootstrapping allowed us to test the mediation hypotheses (Hayes et al. 2011). This study's 5000 resamples generated 95\% confidence intervals (percentile) for the mediators.

Table 1. Measurement model results

\begin{tabular}{|c|c|c|c|}
\hline CONSTRUCT/Dimension/Indicator & Loading & $\begin{array}{l}\text { Composite } \\
\text { reliability } \\
\quad(\mathrm{CR})\end{array}$ & $\begin{array}{l}\text { Average } \\
\text { variance } \\
\text { extracted } \\
\text { (AVE) }\end{array}$ \\
\hline $\begin{array}{l}\text { STRATEGIC IMPLICATION (reflective construct: } \\
\text { strongly disagree (1) to strongly agree (7)) }\end{array}$ & & 0.938 & 0.753 \\
\hline \multicolumn{4}{|l|}{$\begin{array}{l}\text { The board of directors has exercised its authority and has } \\
\text { involved itself in ... }\end{array}$} \\
\hline $\begin{array}{l}\text { making suggestions that, frequently, improve strategic } \\
\text { decisions }\end{array}$ & 0.847 & & \\
\hline $\begin{array}{l}\text { making proposals on long-term strategies and the main } \\
\text { goals }\end{array}$ & 0.868 & & \\
\hline $\begin{array}{l}\text { making decisions on long-term strategies and the main } \\
\text { goals }\end{array}$ & 0.917 & & \\
\hline $\begin{array}{l}\text { putting decisions on long-term strategies and main goals } \\
\text { into action. }\end{array}$ & 0.844 & & \\
\hline $\begin{array}{l}\text { monitoring the follow up of decisions on long-term } \\
\text { strategies and the main goals that have been put into } \\
\text { action }\end{array}$ & 0.862 & & \\
\hline
\end{tabular}


Continue of Table 1

\begin{tabular}{|c|c|c|c|}
\hline CONSTRUCT/Dimension/Indicator & Loading & $\begin{array}{l}\text { Composite } \\
\text { reliability } \\
\quad(\mathrm{CR})\end{array}$ & $\begin{array}{l}\text { Average } \\
\text { variance } \\
\text { extracted } \\
\text { (AVE) }\end{array}$ \\
\hline $\begin{array}{l}\text { PARTNERING PROACTIVENESS (reflective construct: } \\
\text { strongly disagree (1) to strongly agree (7)) }\end{array}$ & & .920 & .699 \\
\hline $\begin{array}{l}\text { We actively monitor our environment to identify } \\
\text { partnering opportunities }\end{array}$ & 0.848 & & \\
\hline $\begin{array}{l}\text { We routinely gather information about prospective partners } \\
\text { from various forums }\end{array}$ & 0.781 & & \\
\hline $\begin{array}{l}\text { We are alert to market developments that create potential } \\
\text { alliance opportunities }\end{array}$ & 0.885 & & \\
\hline $\begin{array}{l}\text { We strive to preempt our competition by entering into } \\
\text { alliances with key firms before they can do so }\end{array}$ & 0.847 & & \\
\hline $\begin{array}{l}\text { We often take the initiative in approaching firms with } \\
\text { alliance proposals }\end{array}$ & 0.815 & & \\
\hline $\begin{array}{l}\text { RELATIONAL GOVERNANCE (reflective construct: } \\
\text { strongly disagree (1) to strongly agree (7)) }\end{array}$ & & 0.830 & 0.555 \\
\hline $\begin{array}{l}\text { Staying together during adversity/challenge is very } \\
\text { important in our relationships }\end{array}$ & 0.573 & & \\
\hline $\begin{array}{l}\text { We endeavour to build relationships based on mutual trust } \\
\text { and commitment }\end{array}$ & 0.797 & & \\
\hline $\begin{array}{l}\text { We strive to be flexible and accommodate partners when } \\
\text { problems/needs arise }\end{array}$ & 0.838 & & \\
\hline $\begin{array}{l}\text { When disagreements arise in our alliances, we usually } \\
\text { reassess facts in an attempt to reach a mutually } \\
\text { satisfactory compromise }\end{array}$ & 0.743 & & \\
\hline $\begin{array}{l}\text { PORTFOLIO COORDINATION (reflective construct: } \\
\text { strongly disagree (1) to strongly agree (7)) }\end{array}$ & & .923 & .707 \\
\hline $\begin{array}{l}\text { We consider our alliances as a portfolio that requires } \\
\text { overall coordination, and not as independent, one-off } \\
\text { arrangements }\end{array}$ & 0.826 & & \\
\hline
\end{tabular}

Our activities across different alliances are well 0.889 coordinated

We systematically coordinate our strategies across different $\quad 0.915$ alliances

We have processes for the systematic transfer of $\quad 0.778$ knowledge between alliance partners

Managers from different departments meet periodically to 0.787 examine how we can create synergies across our alliances

\begin{tabular}{lcc}
\hline $\begin{array}{l}\text { ALLIANCE PORTFOLIO VALUE (aggregate } \\
\text { multidimensional construct) }\end{array}$ & .926 & .646 \\
\hline
\end{tabular}


End of Table 1

\begin{tabular}{cccc}
\hline CONSTRUCT/Dimension/Indicator & Loading & $\begin{array}{c}\text { Composite } \\
\text { reliability } \\
\text { (CR) }\end{array}$ & $\begin{array}{c}\text { Average } \\
\text { variance } \\
\text { extracted } \\
\text { (AVE) }\end{array}$ \\
\hline
\end{tabular}

Alliance portfolio capital (strongly disagree (1) to strongly agree (7)):

Your organization's reputation in the market as a "partner 0.658 of choice"

The competitive strength of your alliance network $\quad 0.739$

Strength of the relationships with alliance partners 0.828

Alliance portfolio performance (strongly disagree (1) to strongly agree (7)):

Overall, we are satisfied with the performance of our $\quad 0.895$ alliances

\begin{tabular}{lccc}
\hline Generally, our alliances satisfy our initial objectives & 0.855 & \\
\hline $\begin{array}{l}\text { Overall we are satisfied with the knowledge accumulated } \\
\text { from participating in alliances }\end{array}$ & 0.881 & \\
\hline Our alliances have been profitable investments & 0.739 & & \\
\hline SIZE & & 1 & 1 \\
\hline Number of employees & 1 & 1 & 1 \\
\hline
\end{tabular}

ALLIANCE EXPERIENCE (strongly disagree (1) to strongly agree (7))

Your organization's experience in managing alliances compared to your competitors

$1 \quad 1$

ALLIANCE FUNCTION (strongly disagree (1) to strongly agree (7))

Your firm has a dedicated department that is dedicated to overseeing its alliance portfolio

$1 \quad 1$

1

BOARD SIZE

The number of directors sitting on the board of an individual company

\section{BOARD COMPOSITION}

\begin{tabular}{|c|c|c|c|}
\hline Outsider directors divided by board size & 1 & 1 & 1 \\
\hline \multicolumn{4}{|l|}{ BOARD ROTATION } \\
\hline Number of directors that changed in the last three years & 1 & 1 & 1 \\
\hline \multicolumn{4}{|l|}{ CEO DUALITY } \\
\hline $\mathrm{CEO}$ and the chairman of the board are the same individual & 1 & 1 & 1 \\
\hline
\end{tabular}




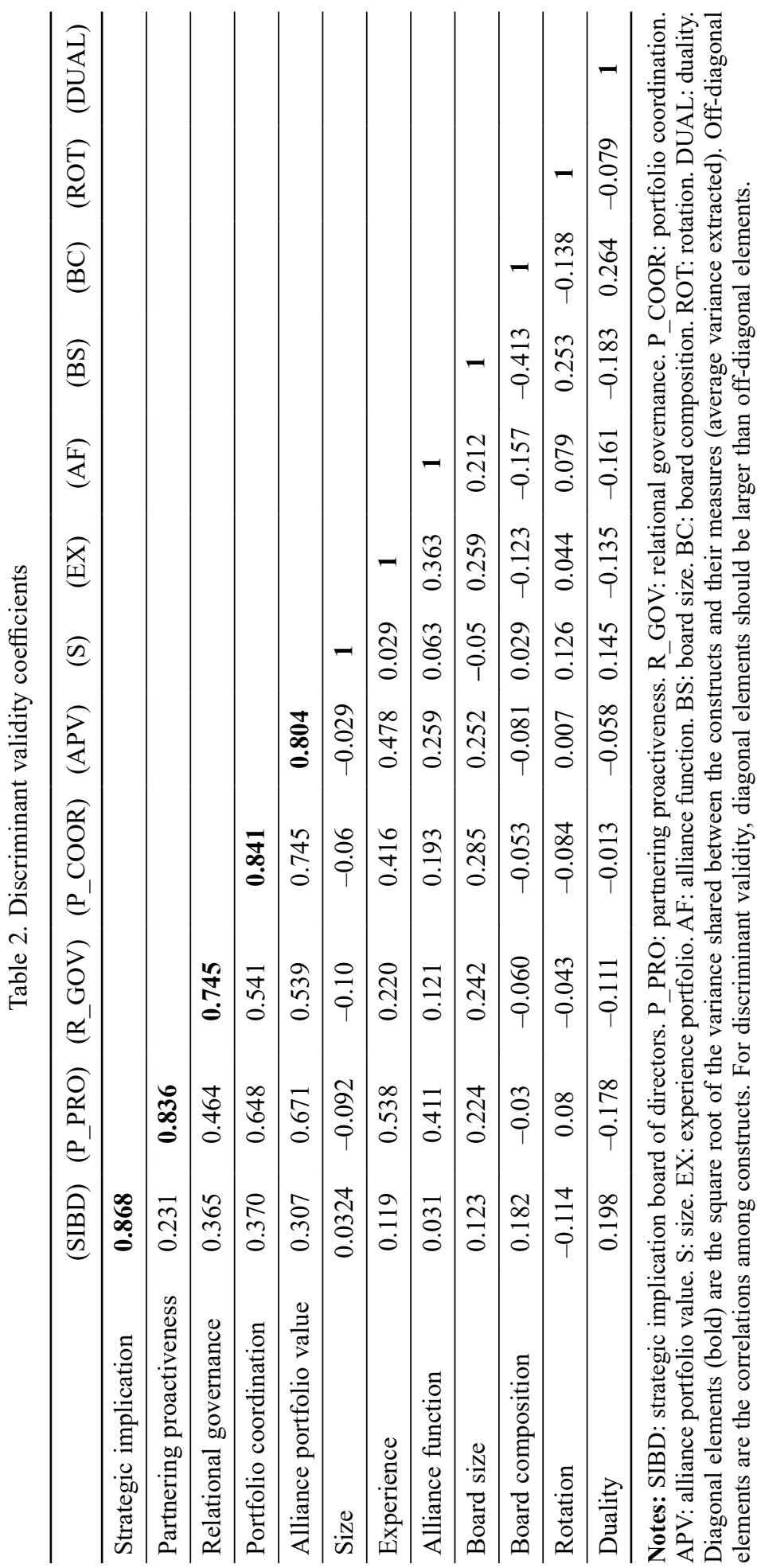




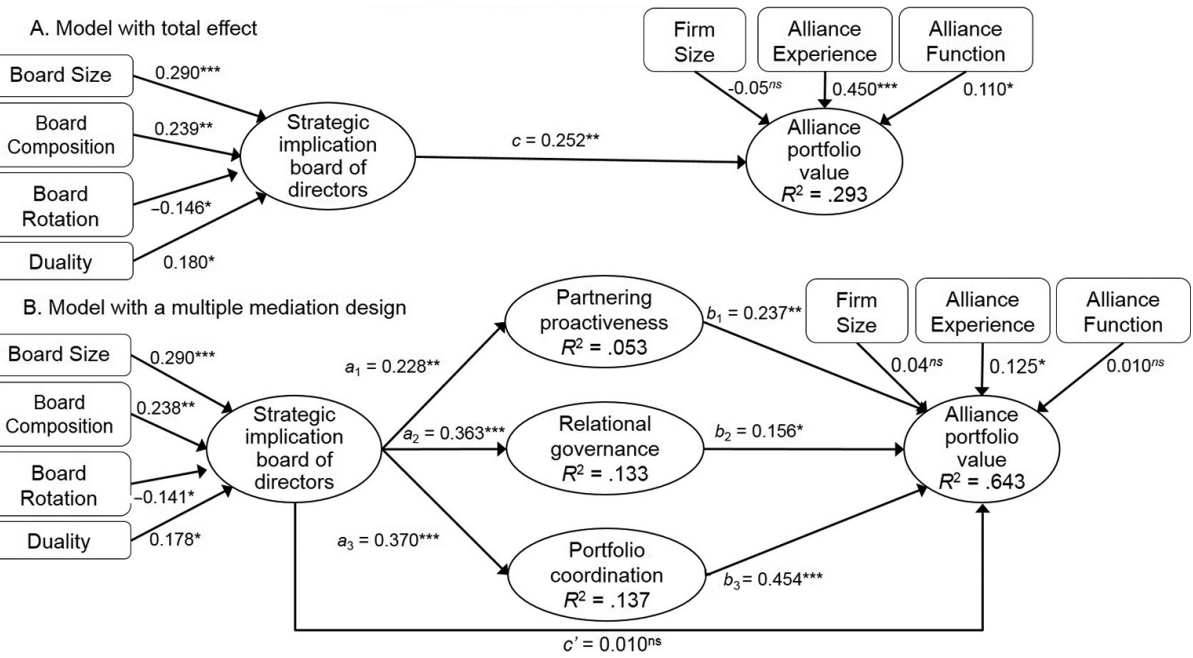

$\mathrm{H} 1=$ Strategic implication board of directors $\rightarrow$ Alliance portfolio value $=c^{\prime}$

$\mathrm{H} 2=$ Strategic implication board of directors $\rightarrow$ Partnering proactiveness $\rightarrow$ Alliance portfolio value $=a_{1} b_{1}$

$\mathrm{H} 3=$ Strategic implication board of directors $\rightarrow$ Relational governance $\rightarrow$ Alliance portfolio value $=a_{2} b_{2}$

$\mathrm{H} 4=$ Strategic implication board of directors $\rightarrow$ Portfolio coordination $\rightarrow$ Alliance portfolio value $=a_{3} b_{3}$

Fig. 1. Structural models results

Table 3. Effects on endogenous variables

\begin{tabular}{|c|c|c|c|c|}
\hline Effects on endogenous variables & Direct effect & $\mathrm{t}$ & $\begin{array}{l}\text { Percentile } 95 \% \\
\text { confidence interval }\end{array}$ & $\begin{array}{l}\text { Explained } \\
\text { variance }\end{array}$ \\
\hline \multicolumn{5}{|l|}{$\begin{array}{l}\text { Partnering proactiveness } \\
\left(R^{2}=0.06 / Q^{2}=0.036\right)\end{array}$} \\
\hline $\operatorname{SIBD}\left(a_{1}\right)$ & $0.227 * *$ & 2.47 & {$[0.057 ; 0.414] \mathrm{Sig}$} & $5.26 \%$ \\
\hline \multicolumn{5}{|l|}{$\begin{array}{l}\text { Relational governance } \\
\left(R^{2}=0.13 / Q^{2}=0.074\right)\end{array}$} \\
\hline SIBD $\left(a_{2}\right)$ & $0.365 * * *$ & 4.181 & {$[0.190 ; 0.535] \mathrm{Sig}$} & $13.24 \%$ \\
\hline \multicolumn{5}{|l|}{$\begin{array}{l}\text { Portfolio coordination } \\
\left(R^{2}=0.13 / Q^{2}=0.095\right)\end{array}$} \\
\hline $\operatorname{SIBD}\left(a_{3}\right)$ & $0.370 * * *$ & 4.823 & {$[0.224 ; 0.528] \mathrm{Sig}$} & $13.68 \%$ \\
\hline \multicolumn{5}{|l|}{$\begin{array}{l}\text { Alliance portfolio value } \\
\left(R^{2}=0.64 / Q^{2}=0.420\right)\end{array}$} \\
\hline P_PRO $\left(b_{1}\right)$ & $0.237 * *$ & 2.483 & {$[0.019 ; 0.407] \mathrm{Sig}$} & $15.98 \%$ \\
\hline R_GOV $\left(b_{2}\right)$ & $0.155^{*}$ & 2.075 & {$[0.009 ; 0.310] \mathrm{Sig}$} & $8.39 \%$ \\
\hline P_COOR $\left(b_{3}\right)$ & $0.453 * * *$ & 5.313 & {$[0.285 ; 0.619] \mathrm{Sig}$} & $33.83 \%$ \\
\hline H1: SIBD $\left(c^{\prime}\right)$ & $0.0104^{\mathrm{ns}}$ & 0.151 & {$[-0.108 ; 0.155] \mathrm{NSig}$} & $0.25 \%$ \\
\hline $\mathrm{S}$ & $0.034^{\mathrm{ns}}$ & 0.70 & {$[-0.070 ; 0.118] \mathrm{NSig}$} & $0.10 \%$ \\
\hline EX & $0.124^{\mathrm{ns}}$ & 1.613 & {$[-0.036 ; 0.266] \mathrm{NSig}$} & $5.97 \%$ \\
\hline $\mathrm{AF}$ & $0.010^{\mathrm{ns}}$ & 0.188 & {$[-0.095 ; 0.111] \mathrm{NSig}$} & $0.26 \%$ \\
\hline
\end{tabular}

Notes: SIBD: strategic implication board of directors; P_PRO: partnering proactiveness; R_GOV: relational governance; $\mathrm{P} \_\mathrm{COOR}$ : portfolio coordination; $\mathrm{APV}$ : alliance portfolio value; $\mathrm{S}$ : size; EX: experience portfolio. AF: alliance function. BS: board size. BC: board composition. ROT: rotation. DUAL: duality. Sig. denotes a significant direct effect at 0.05 ; bootstrapping based on $\mathrm{n}=5.000$ subsamples; $* * * \mathrm{p}<$ $0.001,{ }^{*} \mathrm{p}<0.01,{ }^{*} \mathrm{p}<0.05$, ns: not significant (based on $\mathrm{t}(4999)$, one-tailed test); $\mathrm{t}(0.05,4999)=$ $1.65, \mathrm{t}(0.01,4999)=2.33, \mathrm{t}(0.001,4999)=3.09$. 


\section{Findings and discussion}

Table 4 shows the results of the tests on the mediating effects of the variables. The SIBD had a significant total effect on APV $(c=0.252$, $t$-value $=2.703)$ (Fig. 1A). When the mediators were introduced, the strategic involvement of the boards of directors no longer had a significant direct effect on alliance portfolio value $\left(\mathrm{H} 1\right.$ : $\mathrm{c}^{\prime}=0.010, \mathrm{t}$ value $=0.151)$. This means that $P_{-}$PRO, R_GOV, P_COOR fully mediated the influence of the strategic involvement of boards of directors on alliance portfolio value. Indeed, as previously mentioned, $\mathrm{H} 1$ was not supported. However, no CIs contained zero, so the indirect effects were significant. Consequently, support is found for $\mathrm{H} 2-\mathrm{H} 4$, which means that the three indirect effects of SIBD on APV in our research model were significant (Fig. 1B). Finally, the results show that the SIBD had a total indirect effect on APV (point estimate $=0.278$ ), which was higher than its direct effect (point estimate $=$ $0.010)$.

In relation to the control variables included in our model, size and alliance function presented a negligible and non-significant paths and alliance experience presented a significant path. Meanwhile, experience with alliances affected the relation between SIBD on APV in both a positive and significant manner (Fig. 1A). However, the influence of that experience on the capability that the organization has been able to develop was reduced, when alliance portfolio management capabilities were introduced as mediating dimensions. This finding highlights the importance of using knowledge acquired over time in the management of alliances, to develop organizational skills and capabilities that improve the performance of the portfolio.

Related to the antecedents of the SIBD, Table 4 shows that the size of the board of directors, its composition and CEO duality affected the SIBD in a positive and significant way. On the contrary, the rotation of these boards of directors had a negative and significant impact on that involvement. So, Pearce II and Zahra (1992) pointed out that board composition, including the size and types and characteristics of board membership, will impact on the capability to provide strategic direction and performance. Thus, as the authors have pointed out, the literature has provided sufficient evidence that the capability of the boards of directors to fulfil their responsibilities, with regard to service, strategy and control, depends on their composition. Along these lines, it is noted that larger boards of directors make more significant contributions to strategy. In relation to CEO duality, the results obtained in the literature are divergent and many of them show an absence of correlation and significant meaning (Ruigrok et al. 2006; Zahra, Pearce II 1990). In this sense, the results obtained in our work appear to support the stewardship theory (Muth, Donaldson 1998), showing that clear leadership that arises from CEO duality is very valuable when the situation requires fast decisions and clear strategic orientation (Ruigrok et al. 2006). Thus, the firms that are increasingly involved in a larger number of alliances require a clear holistic, strategic focus to obtain their maximum performance, which may be helped by CEO duality. Finally, Zahra and Pearce II (1990) pointed out that the experience of the directors defined, among other factors by their familiarity with the operations of the company, is positively related to 
the level of strategic involvement of the board. So, the existence of frequent changes in the directors that constitute the board will be detrimental to board expertise. Accordingly, the results show that changes in the board of directors impacts on the SIBD in a negative and significant way.

With a view to studying the relations between the SIBD and alliance portfolio management, we proposed a model where macro-forces, based on theoretical approaches of corporate governance, interact with micro dynamics that attempt to encompass organizational processes and dimensions and which require the strategic management of alliance portfolios (Wassmer 2010). The model was analysed with data from 139 large Spanish firms and its hypotheses were tested through the application of a statistical mediation analysis.

Table 4. Summary of mediating effect tests

\begin{tabular}{|c|c|c|c|c|c|c|c|c|c|}
\hline \multicolumn{3}{|c|}{ Total effect on APV } & \multicolumn{3}{|c|}{ Direct effects on APV } & \multicolumn{4}{|c|}{ Indirect effects on APV } \\
\hline & \multirow[t]{2}{*}{ Path } & \multirow[t]{2}{*}{$\mathrm{t}$} & & \multirow[t]{2}{*}{ Path } & \multirow[t]{2}{*}{$\mathrm{t}$} & \multicolumn{4}{|c|}{$\begin{array}{c}\text { Percentile bootstrap } \\
95 \% \text { confidence } \\
\text { interval }\end{array}$} \\
\hline & & & & & & & $\begin{array}{c}\text { Point } \\
\text { estimate }\end{array}$ & Lower & Upper \\
\hline \multirow[t]{4}{*}{$\begin{array}{l}\text { SIBD } \\
(c)\end{array}$} & $0.252 * *$ & 2.703 & $\mathbf{H 1}=c^{\prime}$ & $0.010^{\mathrm{ns}}$ & 0.151 & $\begin{array}{c}\text { Total }= \\
a_{1} b_{1}+ \\
a_{2} b_{2}+ \\
a_{3} b_{3}\end{array}$ & 0.278 & 0.17 & 0.404 Sig. \\
\hline & & & & & & $\begin{array}{c}\mathbf{H 2}=a_{1} b_{1} \\
(\text { via P_PRO) }\end{array}$ & 0.054 & 0.003 & 0.129 Sig. \\
\hline & & & & & & $\begin{array}{c}\mathbf{H 3}=a_{2} b_{2} \\
(\text { via R_GOV) }\end{array}$ & 0.056 & 0.003 & 0.127 Sig. \\
\hline & & & & & & $\begin{array}{c}\mathbf{H 4}=a_{3} b_{3} \\
\text { (via P_COOR) }\end{array}$ & 0.167 & 0.087 & 0.276 Sig. \\
\hline $\mathrm{S}$ & $-0.05^{\mathrm{ns}}$ & 0.751 & $\mathrm{~S}$ & $0.034^{\mathrm{ns}}$ & 0.70 & & & & \\
\hline EX & $0.450 * * *$ & 4.318 & EXP & $0.124^{*}$ & 1.671 & & & & \\
\hline $\mathrm{AF}$ & $0.110^{*}$ & 1.754 & $\mathrm{AF}$ & $0.010^{\mathrm{ns}}$ & 0.188 & & & & \\
\hline BS & $0.290 * * *$ & 3.639 & BS & $0.289 * * *$ & 3.84 & & & & \\
\hline $\mathrm{BC}$ & $0.239 * *$ & 2.771 & $\mathrm{BC}$ & $0.236^{* *}$ & 2.80 & & & & \\
\hline ROT & $-0.146^{*}$ & 2.013 & ROT & $-0.141^{*}$ & 1.87 & & & & \\
\hline DUAL & $0.180^{*}$ & 2.112 & DUAL & $0.178^{*}$ & 2.11 & & & & \\
\hline
\end{tabular}

Notes: SIBD: strategic implication board of directors; P_PRO: partnering proactiveness; R_GOV: relational governance; P_COOR: portfolio coordination; APV: alliance portfolio value; S: Size; EX: experience portfolio. AF: alliance function. BS: board size. BC: board composition. ROT: rotation. DUAL: duality. Sig. denotes a significant direct effect at 0.05 ; bootstrapping based on $n=5.000$ subsamples; ${ }^{* * *} \mathrm{p}<0.001,{ }^{* *} \mathrm{p}<0.01,{ }^{*} \mathrm{p}<0.05$, ns: not significant (based on $t(4999)$, one-tailed test); $\mathrm{t}(0.05,4999)=1.65, \mathrm{t}(0.01,4999)=2.33, \mathrm{t}(0.001,4999)=3.09$. Nsig. denotes a nonsignificant direct effect at 0.05 . 
The results showed that $\mathrm{P}_{-} \mathrm{PRO}, \mathrm{R}$ _GOV, $\mathrm{P}_{-}$COOR fully mediated the effect of the strategic involvement of boards of directors on alliance portfolio value. The results therefore support the three hypotheses of the study: P_PRO (H2), R_GOV (H3), and P_COOR (H4). Accordingly, the three dimensions identified by Sarkar et al. (2009) presented a positive and significative relation with the APV. In fact, the P_COOR dimension represented the best predictor of the APV, as it explained $33.83 \%$ of its variance. Thus, these results support the extrapolation or generalization of the findings of these researchers in a different empirical context. On the contrary, the direct relation between the SIBD and APV (H1) was not significative. Our results contribute to the literature, insofar as these relations had not been analysed beforehand (Reuer, Ragozzino 2006). Thus, on the one hand, the results appear to support the ideas of those authors that call for greater participation of the boards of directors in the strategies (Ruigrok et al. 2006). The results for the model with the total effect (Fig. 1A) indicated that the SIBD had a significant total effect on APV. However, the importance of the direct effect of the SIBD on APV almost entirely disappeared when we analyzed the full model (Fig. 1B). Thus, the study showed that the SIBD had a positive and significative impact on organizational processes linked to the management of alliance portfolios, proposing, therefore, the importance and the need for more active participation of the directors in strategic decisions, with the objective of ensuring holistic management that is more effective and more efficient. On the other hand, as proposed in the theoretical background to this study, Zahra and Pearce II (1989) pointed out that the impact of the boards of directors on the performance of the firm can occur, either directly, through a series of attributes of the boards of directors, or in an indirect way, through the functions and roles that they perform. Likewise, Heracleous (2001) affirmed that researchers should avoid models that establish a direct relation between the boards of directors and performance. On the contrary, he argued that the functions performed by these boards, in particular, their active involvement in strategic decisions for the alliance portfolios, will impact on more efficient and effective management.

\section{Conclusions}

In conclusion, this study has helped to demystify the complex relationships between the strategic involvement of boards of directors and the results linked to the management of the alliance portfolio.

The main theoretical contribution of this investigative study is its arrival at a deeper understanding of the role that the boards of directors might have in terms of assessment and participation in strategic decisions at a corporate level, centring on the management of alliance portfolios. Thus, from the perspective of the function of service, the results demonstrate that one consequence of the active involvement of the board of directors in strategic decisions is further development of the capabilities of the firm, in this case of the alliance portfolio management capability, but active involvement has no direct effect on performance; this effect is produced through greater fulfilment of the capabilities of the organization. Moreover, this work has shown that there are a series of antecedent factors or variables that can facilitate or complicate the strategic involvement of the board of directors in the management of the alliances that constitute the portfolio. 
At an empirical level, the study has shown that the strategic involvement of the board of directors has a positive and significative influence on the different organizational processes linked to the management of alliance portfolios, thereby influencing the value of that portfolio. The practical implications of this study, both for managers and for directors, should contribute to reflection on the management of alliance portfolios. Accordingly, the literature has centred a lot on the supervisory role, but much less so on the consultancy function or strategic function, where active participation in evaluating and managing strategic alliances as a whole may be decisive, in order to generate greater collaborative synergies and, consequentially, to increase the value of the alliance portfolio. The results have confirmed the suggestions of Hoffmann (2005) on the necessary involvement of boards of directors to carry out effective management of the alliance portfolio.

This research also presents a series of limitations, although each one could form the basis for future lines of research that would complement its principal findings. From an empirical perspective, a first limitation is that a sample of firms has been analysed from one particular country (Spain) and with specific characteristics (established MNCs), which could have certain drawbacks when generalizing and extrapolating any results. In second place, alliance portfolio management is a dynamic organizational process, however, we were unable to conduct a longitudinal analysis in this study. Performing a longitudinal study might therefore constitute an interesting line of future research. Finally, a series of factors impacts on the capability of the board to manage the alliance portfolio. In this work, we have analysed the involvement of boards of directors, but it would be interesting to introduce both other contextual variables with a view to gaining a better understanding of this capability and its consequences and the moderating or mediating roles of other variables related to the attributes of the board of directors.

\section{Acknowledgements}

This research was supported by the Ministerio de Economía y Competitividad, Spain (ECO2013-45329-R).

\section{References}

Casanueva, C; Gallego, A.; Castro, I.; Sancho, M. 2014. Airline alliances: mobilizing network resources, Tourism Management 44: 88-98. http://dx.doi.org/10.1016/j.tourman.2014.02.011

Castro, I.; Roldán, J. L. 2013. A mediation model between dimensions of social capital, International Business Review 22(6): 1034-1050. http://dx.doi.org/10.1016/j.ibusrev.2013.02.004

Das, T. K.; Teng, B. S. 2000. A resource based theory of strategic alliances, Journal of Management 26: 31-61. http://dx.doi.org/10.1177/014920630002600105

Granovetter, M. 1992. Problems of explanation in economic sociology, in N. Nohria, R. G. Eccles (Eds.). Networks and organizations: structure, form, and action. Harvard Business School Press, 25-56.

Geringer, J. M.; Hebert, L. 1991. Measuring performance of international joint ventures, Journal of International Business Studies 22(2): 249-263. http://dx.doi.org/10.1057/palgrave.jibs.8490302 Hayes, A. F.; Preacher, K. J.; Myers, T. A. 2011. Mediation and the estimation of indirect effects in political communication research, in E. P. Bucy, R. L. Holbert (Eds.). Sourcebook for political communication research: methods, measures, and analytical techniques. Routledge, 434-465. 
He, J.; Mahoney, J. T.; Wang, H. C. 2010. Firm capability, corporate governance and competitive behaviour: a multi-theoretic framework, International Journal of Strategic Change Management 1(4): 293-318. http://dx.doi.org/10.1504/IJSCM.2009.031408

Henseler, J.; Ringle, C. M.; Sinkovics, R. R. 2009. The use of partial least squares path modeling in international marketing, Advances in International Marketing 20: 277-320.

http://dx.doi.org/10.1108/S1474-7979(2009)0000020014

Heracleous, L. 2001. What is the impact of corporate governance on organisational performance?, Corporate Governance 9(3): 165-173. http://dx.doi.org/10.1111/1467-8683.00244

Hoffmann, W. H. 2005. How to manage a portfolio of alliances, Long Range Planning 38(2): 121-143. http://dx.doi.org/10.1016/j.lrp.2005.03.001

Huse, M.; Zattoni, A. 2008. Trust, firm life cycle, and actual board behavior: evidence from "one of the lads" in the board of three small firms, International Studies of Management \& Organization 38(3): 71-97. http://dx.doi.org/10.2753/IMO0020-8825380303

Khanna, T.; Gulati, R.; Nohria, N. 1998. The dynamics of learning alliances: competition, cooperation, and relative scope, Strategic Management Journal 19(3): 193-210.

http://dx.doi.org/10.1002/(SICI)1097-0266(199803)19:3<193::AID-SMJ949>3.0.CO;2-C

Kor, Y. Y.; Sundaramurthy, C. 2009. Experience-based human capital and social capital of outside directors, Journal of Management 35(4): 981-1006. http://dx.doi.org/10.1177/0149206308321551

Lahiri, N.; Narayanan, S. 2013. Vertical integration, innovation and alliance portfolio size: implications for firm performance, Strategic Management Journal 34: 1042-1064.

http://dx.doi.org/10.1002/smj.2045

Liang, H. N.; Saraf, Q. H.; Xue, Y. 2007. Assimilation of enterprise systems: the effect of institutional pressures and the mediating role of top management, MIS Quarterly 31(1): 59-87.

McNulty, T.; Pettigrew, A. 1999. Strategists on the board, Organization Studies 20(1): 47-74. http://dx.doi.org/10.1177/0170840699201003

Muth, M. M.; Donaldson, L. 1998. Stewardship theory and board structure: a contingency approach, Corporate Governance 6(1): 5-28. http://dx.doi.org/10.1111/1467-8683.00076

Oerlemans, L. A. G.; Knoben, J.; Pretorius, M. W. 2013. Alliance portfolio diversity, radical and incremental innovation: the moderating role of technology management, Technovation 33: 234-246. http://dx.doi.org/10.1016/j.technovation.2013.02.004

Pearce II, J. A.; Zahra, S. 1992. Board composition from a strategic contingency perspective, Journal of Management Studies 29(4): 411-438.

http://dx.doi.org/10.1111/j.1467-6486.1992.tb00672.x

Reuer, J. J.; Ragozzino, R. 2006. Agency hazards and alliance portfolios, Strategic Management Journal 27(1): 27-43. http://dx.doi.org/10.1002/smj.446

Ringle, C. M.; Wende, S.; Will, A. 2005, SmartPLS 2.0 (Beta). Hamburg: University of Hamburg. Roberts, J.; NcNulty, T.; Stiles, P. 2005. Beyond agency conceptions of the work of the nonexecutive director: creating accountability in the boardroom, British Journal of Management 16(s1): S5-S26. http://dx.doi.org/10.1111/j.1467-8551.2005.00444.x

Ruigrok, W.; Peck, S. I.; Keller, H. 2006. Board characteristics and involvement in strategic decision making: evidence from Swiss companies, Journal of Management Studies 43(5): 1201-1226. http://dx.doi.org/10.1111/j.1467-6486.2006.00634.x

Sarkar, M. B.; Aulakh, P. H.; Madhok, A. 2009. Process capabilities and value generation in alliance portfolios, Organization Science 20(3): 583-600. http://dx.doi.org/10.1287/orsc.1080.0390

Schilke, O.; Goerzen, A. 2010. Alliance management capability: an investigation of the construct and its measurement, Journal of Management 36(5): 1192-1219.

http://dx.doi.org/10.1177/0149206310362102 
Schreiner, M.; Kale, P.; Corsten, D. 2009. What really is alliance management capability and how does it impact alliance outcomes and success?, Strategic Management Journal 30(13): 1395-1419. http://dx.doi.org/10.1002/smj.790

Sepulveda, F.; Gabrielsson, M. 2013. Network development and firm growth: a resource-based study of B2B born globals, Industrial Marketing Management 42: 792-804.

http://dx.doi.org/10.1016/j.indmarman.2013.01.001

Simoni, M.; Caiazza, R. 2012. Interlocks network structure as driving force of coopetition among Italian firms, Corporate Governance 12(3): 319-336. http://dx.doi.org/10.1108/14720701211234582

Sluyts, K.; Matthyssens, P.; Martens, R.; Streukens, S. 2011. Building capabilities to manage strategic alliances, Industrial Marketing Management 40: 875-886.

http://dx.doi.org/10.1016/j.indmarman.2011.06.022

Tang, Y. K. 2011. The influence of networking on the internationalization of SMEs: evidence from internationalized Chinese firms, International Small Business Journal 29: 374-398. http://dx.doi.org/10.1177/0266242610369748

Vandaie, R.; Zaheer, A. 2014. Surviving bear hugs: firm capability, large partner alliances, and growth, Strategic Management Journal 35: 566-577. http://dx.doi.org/10.1002/smj.2115

Wassmer, U. 2010. Alliance portfolios: a review and research agenda, Journal of Management 36(1): 141-171. http://dx.doi.org/10.1177/0149206308328484

Wassmer, U.; Dussauge, P. 2012. Network resource stocks and flows: how do alliance portfolios affect the value of new alliance formations?, Strategic Management Journal 8: 871-883.

http://dx.doi.org/10.1002/smj.973

Wincent, J.; Anokhin, S.; Örtqvist, D. 2010. Does network board capital matter? A study of innovative performance in strategic SME networks, Journal of Business Research 63(3): 265-275. http://dx.doi.org/10.1016/j.jbusres.2009.03.012

Zahra, S. A.; Pearce II, J. A. 1989. Boards of directors and corporate financial performance: a review and integrative model, Journal of Management 15(2): 291-334.

http://dx.doi.org/10.1177/014920638901500208

Zahra, S. A.; Pearce, J. A. 1990. Determinants of board directors' strategic involvement, European Management Journal 8(2): 164-173. http://dx.doi.org/10.1016/0263-2373(90)90082-H

Ignacio CASTRO, Dr, is an Associate Professor of Management at the Faculty of Economics and Business Administration, University of Seville. His main research interests are inter-organizational relationship, social capital, strategic alliances, alliance portfolio and innovation. He has published in Journal Business Research, International Business Review, European Management Journal and Tourism Management. Dr. Castro has taught at several Ph.D. programs in Spain and other countries.

José L. GALÁN, Dr, is a Professor of Strategy \& Organization at the University of Sevilla, being his area of expertise Strategic Management. His research has appeared in leading journals that include the Strategic Management Journal, Journal of Management Studies, Journal of Business Venturing, Management Decision, Journal of Business Research, Journal of Knowledge Management, among others. Dr. Galán has also developed an intense activity related to management consulting and coordination of research groups.

Cristóbal CASANUEVA, Dr, is an Assistant Professor of Management and Strategic Management at the Tourism School of the University of Seville. His main research interests are inter-organizational relationships, cooperatives firms, tourism, and education innovation. He has published in journals such as Journal of Management Studies, Tourism Management or Journal of Business Research. 